\title{
Actinotus periculosus (Apiaceae): a new perennial species from eastern Australia
}

\author{
M.J. Henwood
}

\begin{abstract}
M.J. Henwood (John Ray Herbarium, School of Biological Sciences (A12), The University of Sydney, NSW 2006, Australia). 2000. Actinotus periculosus (Apiaceae): a new perennial species from eastern Australia. Telopea 8(4): 455-459. A new perennial species, Actinotus periculosus, is described from the Leichhardt District of Queensland. A. periculosus is allied to A. helianthi (New South Wales and Queensland) and A. schwarzii (Northern Territory), but is separable from these species by its larger, deeply dissected leaves and relatively long gynoecial column. A key to all species of Actinotus from eastern and central Australia is provided.
\end{abstract}

\section{Introduction}

Actinotus as it is currently circumscribed comprises 17 species. The genus is most diverse within Australia, and is represented by a single endemic species, A. novaezelandiae (Petrie) Petrie, in New Zealand. Within the Australian Apiaceae, Actinotus is recognisable on account of its compressed monocarpic fruit, and its often showy involucral bracts forming pseudanthial umbels or capitula. The single-seeded monocarp is apparently derived from the more common bicarpellate gynoecium, for it initially contains two ovules, one of which subsequently fails to develop beyond a rudimentary structure (Magin 1977).

One of the most widespread Australian perennial species is A. helianthi, which ranges from Merimbula (36 $\left.54^{\prime} \mathrm{S}, 149^{\circ} 54^{\prime} \mathrm{E}\right)$ in southern New South Wales to Rolleston $\left(24^{\circ} 27^{\prime} \mathrm{S}, 148^{\circ} 37^{\prime} \mathrm{E}\right)$ in Queensland. Two leaf forms can be discerned within A. helianthi. Plants from coastal heaths (at the top of sea cliffs or on stable coastal dunes) are more robust and have less dissected leaves than plants from woodland habitats. When grown in common gardens these morphological differences are maintained, thereby appearing to be genetically fixed (von Richter pers. comm.).

Together with A. schwarzii (restricted to the cliff faces of the MacDonell Ranges; Northern Territory), Actinotus helianthi constitutes a morphologically distinct group within the genus. Both species are morphologically closely allied and share several unique, apparently derived characters namely: more or less filamentous petals, an elongated restriction (column) above the ovary and long horn-like nectaries inserted at the base of the styles.

Actinotus helianthi reaches its northern-most limit in the vicinity of the Carnarvon range (Queensland). The Carnarvon range is formed in large part by the outcropping of Jurassic, Precipice sandstone which marks the northern boundary of the Surat basin. The horizontally bedded Precipice sandstone is deeply dissected and forms vertical cliffs up to $200 \mathrm{~m}$ high. A perennial taxon closely resembling the 'woodland' form of A. helianthi has been recorded from the cliffs of the Carnarvon range and is here described as a new species. 


\section{Taxonomy}

\section{Actinotus periculosus Henwood, sp. nov.}

Actinotus helianthi Labill. et $A$. schwarzii F. Muell affinis. A. helianthi foliis magis penitus et subtiliter dissectis, collis longioribus differt. A. schwarzii foliis majoribus stipellis basalibus destitutus, collis brevioribus, petalis filamentosis differt.

Type: Queensland: Leichhardt District: $15 \mathrm{~km} \mathrm{~N}$ of 'The Tombs' on Marlong Creek, Mt Moffat region of Carnarvon National Park, M.J. Henwood 511, 19 Oct 1998 (holo SYD; iso BRI, NSW).

Plants andromonoecious, erect to ascending, perennial, to $20-50 \mathrm{~cm}$ high. Stems branching, covered in dense white felted indumentum. Leaves cauline, discolorous, alternate, ternately dissected, petiolate. Sheaths 6-9 $\mathrm{mm}$ long, sericeous and felted. Petioles 15-54 mm long, adaxially grooved. Laminas 20-100 mm long, 15-70 mm wide, finely dissected. Primary segments elliptic to linear, (20-)30-65 long, 1-5(-6) $\mathrm{mm}$ wide, apices acute or obtuse. Umbels capitulum-like, pseudanthial, borne in monochasial cymes, subtended by trifid bracts. Peduncles 30-90 mm long. Umbels 15-30 mm in diameter, 94-310 flowered. Involucral bracts 9-12, apparently arranged in a single whorl; 25-55 mm long, 5-16 mm wide; lamina hairy, white with green tips, venation distinct. Bisexual flowers borne centrally in 'capitula' and surrounded by a peripheral ring (or rings) of male flowers. Anthesis proceeds centrifugally in each umbel. Bisexual flowers protandrous. Pedicels 4-4.5 $\mathrm{mm}$ long, articulated at junction with the gynophore, sparsely villous. Gynophores $3.4-4 \mathrm{~mm}$ long, villous. Sepals conspicuous, petaloid, ovate, 1-1.5 mm long, $0.5-0.75 \mathrm{~mm}$ wide, white to cream, bases truncate, apices acute, villous. Petals inconspicuous, filamentous, $0.8-0.95 \mathrm{~mm}$ long, glabrous. Stamens 5; filaments 1.7-2.5 mm long; anthers dorsifixed, 0.4-0.5 mm long. Stylopodia $0.5-0.9 \mathrm{~mm}$ high, glabrous. Nectaries 2, each a horn-like projection inserted directly below each style, $0.3 \mathrm{~mm}$ long, dark purple, glabrous. Ovaries unilocular, villous, surmounted by a column; column $2.4-3 \mathrm{~mm}$ long, villous. Styles 2, arranged parallel to the plane of ovary compression, 1.4-2 $\mathrm{mm}$ long. Male flowers characterised by a much reduced (non-functional) gynoecium, otherwise similar to bisexual flowers. Mature fruit not seen. (Fig. 1).

Distribution and habitat: endemic to the Leichhardt District of Queensland. Restricted to sandstone cliff faces (Fig. 2).

Notes: The characteristically deeply dissected leaves with narrow, linear segments of $A$. periculosus do not correspond to either the woodland or the heath leaf forms of $A$. helianthi. Individuals of $A$. periculosus are further separable from $A$. helianthi by the former's longer gynoecial columns (2.4-3.0 mm long). Based on observations from one flowering season, $A$. helianthi and A. periculosus appear to be reproductively isolated when in sympatry - for example at Spyglass Mountain, in the Salvator Rosa region of Carnarvon National. In such localities A. helianthi is fruiting whilst A. periculosus is at early anthesis.

Actinotus periculosus is likewise easily separable from A. schwarzii. Like A. helianthi, leaves of $A$. periculosus lack the pair of basal basiscopic, stipel-like lobes that characterise the leaves of $A$. schwarzii. In addition, the length of the gynoecial columns of both $A$. helianthi and $A$. periculosus are not as long as those of $A$. schwarzii ( $\geq 3.0 \mathrm{~mm}$ long) and the petals of $A$. schwarzii are apically broader than those of the other species (Powell (1992) and others have erroneously described $A$. helianthi as apetalous). Given the apparent reproductive isolation of $A$. periculosus from $A$. helianthi when in sympatry, combined with obvious differences in reproductive and vegetative morphology, it is clear that $A$. periculosus does, in fact, warrant formal segregation from $A$. helianthi.

Flowering: October and November 
Etymology: from the Latin periculosus, dangerous, in reference to the difficulty experienced in obtaining representative specimens of this species from sandstone cliffs.

Conservation status: this species is not regarded as rare and is adequately protected.

Selected specimens: Queensland: Leichhardt: 'The Tombs', c. $143 \mathrm{~km}$ from Injune, Mt Moffatt section of Carnarvon National Park, Henwood 508,18 Oct 1998 (BRI, NSW, SYD); $15 \mathrm{~km} \mathrm{~N}$ of 'The Tombs' on Marlong creek, Mt Moffat region of Carnarvon National Park, Henwood 511, 19 Oct 1998 (BRI, NSW, SYD); Lookout at Lonesome National Park, Henwood 513, 19 Oct 1998 (BRI, NSW, SYD); 'Balloon Cave', Carnarvon Gorge, Carnarvon National Park, Henwood 517, 21 Oct 1998 (BRI, NSW, SYD); 'Spyglass Peak' Salvator Rosa section of Carnarvon National Park, Henwood 518, 21 Oct 1998 (BRI, NSW, SYD); c. 100 m north of Get Down track, Robinson National Park, Henwood 520, 23 Oct 1998 (BRI, NSW, SYD).

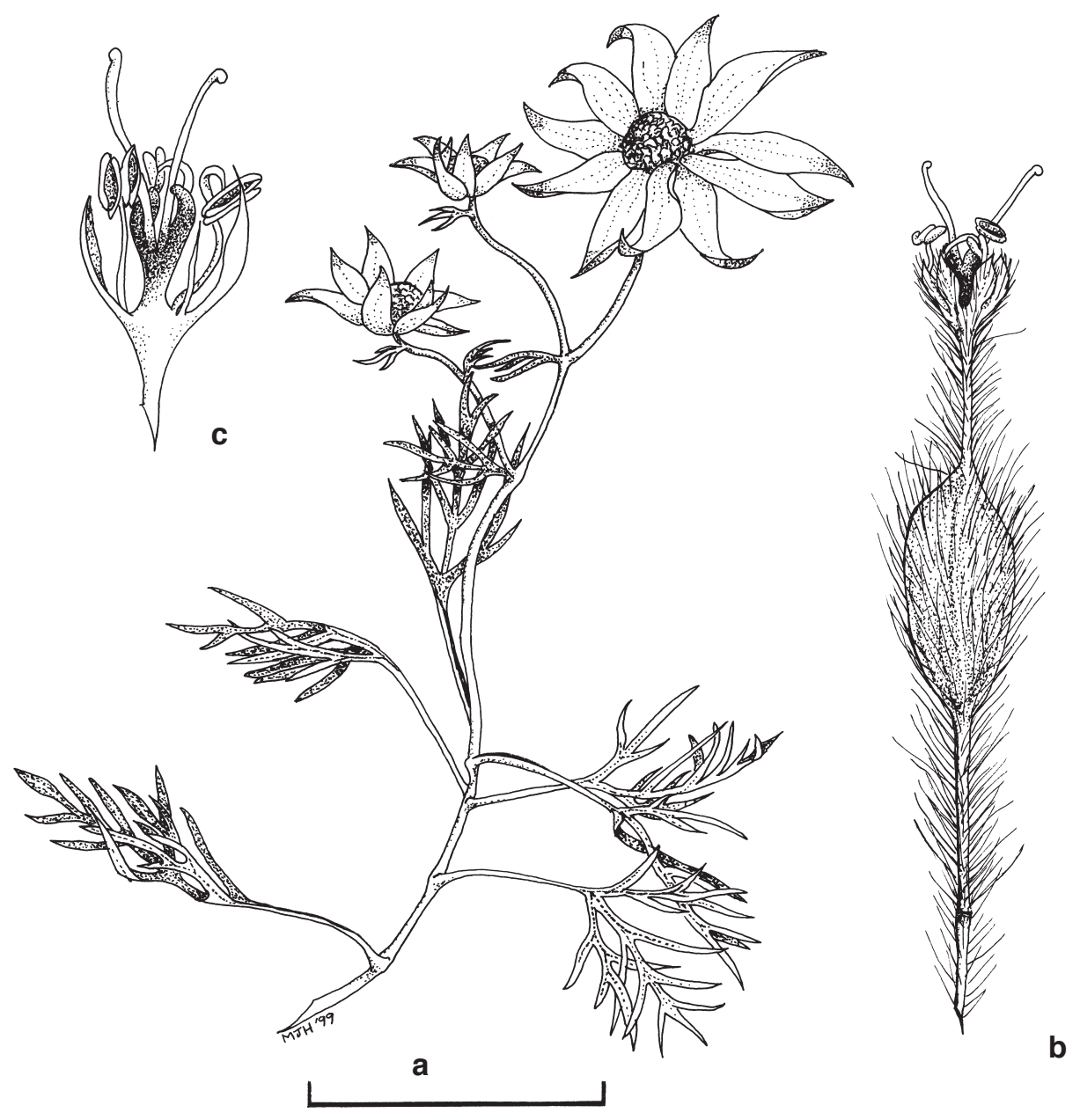

Fig. 1. Actinotus periculosus (from Henwood 511). a, foliose upper portion of branch with inflorescence; $\mathbf{b}$, hermaphrodite flower; $\mathbf{c}$, apex of gynoecial column with 3 sepals, 4 petals and 2 stamens removed (trichomes not illustrated). Scale bar: $a=100 \mathrm{~mm} ; b=5 \mathrm{~mm} ; \mathrm{c}=4 \mathrm{~mm}$. 


\section{Key to eastern and central Australian species of Actinotus}

1 Leaves dissected; flowers in capituloid umbels; bracts > $19 \mathrm{~mm}$ long; gynophores present; columns present; petals filamentous

2 Leaf laminas without basal, basiscopic lobes; column $£ 3 \mathrm{~mm}$ long; petals hair-like, not apically expanded

3 Leaf segments long-linear; column 2.4-3 mm long. Qld.

A. periculosus $3^{*}$

Leaf segements broadly linear; column $£ 1 \mathrm{~mm}$ long. Vic., N.S.W., Qld.

A. helianthi

2* Leaf laminas with basal, basiscopic lobes; column - $3 \mathrm{~mm}$ long; petals slightly apically expanded. N.T.

A. schwarzii

$1^{*}$ Leaves entire, toothed or dissected; flowers in capitula or capituloid umbels; bracts < $10 \mathrm{~mm}$ long; gynophores absent; columns absent; petals, when present, spathulate

4 Plants cushion-forming to $7 \mathrm{~cm}$ high; capitula with 5-12 flowers, not pseudanthial; bracts 1.5-3.0 mm long; flowers sessile; petals absent; fruit weakly laterally flattened 5

5 Leaves entire, crenulate or shallowly trilobed; sepals free 6

6 Leaves entire; stamens 2-3. Tas. A. suffocatus

$6^{*}$ Leaves crenulate or shallowly trilobed; stamens 5. Tas., Vic.

A. bellidioides

$5^{*}$ Leaves dissected; sepals basally connate; stamens 2 . Tas.

A. moorei

4* Plants erect, procumbent or decumbent, never cushion-forming, usually $>5 \mathrm{~cm}$ high; umbels or capitula with 16-68 flowers, pseudanthial; bracts $4.0-10 \mathrm{~mm}$ long; flowers pedicellate; petals absent or present; fruit strongly laterally flattened

7 Plants erect to procumbent; sepals free or connate for most of their length; peduncles 45-150 $\mathrm{mm}$ long 8

8 Involucral bracts 1-whorled; petals absent, sepals free. N.S.W.

A. minor

8* Involucral bracts 2-whorled; petals spathulate; sepals connate for most of their length. Vic., N.S.W.

A. forsythii

7* Plants spreading to weakly erect; sepals basally connate; petals spathulate; peduncles $1-8 \mathrm{~mm}$ long 9

9 Fruit winged, fringed with short trichomes; stamens 3; involucral bracts basally connate. N.S.W., Qld.

A. paddisonii

9* Fruit not winged, fringed with long trichomes; stamens 5; involucral bracts free. N.S.W., Qld.

A. gibbonsii 


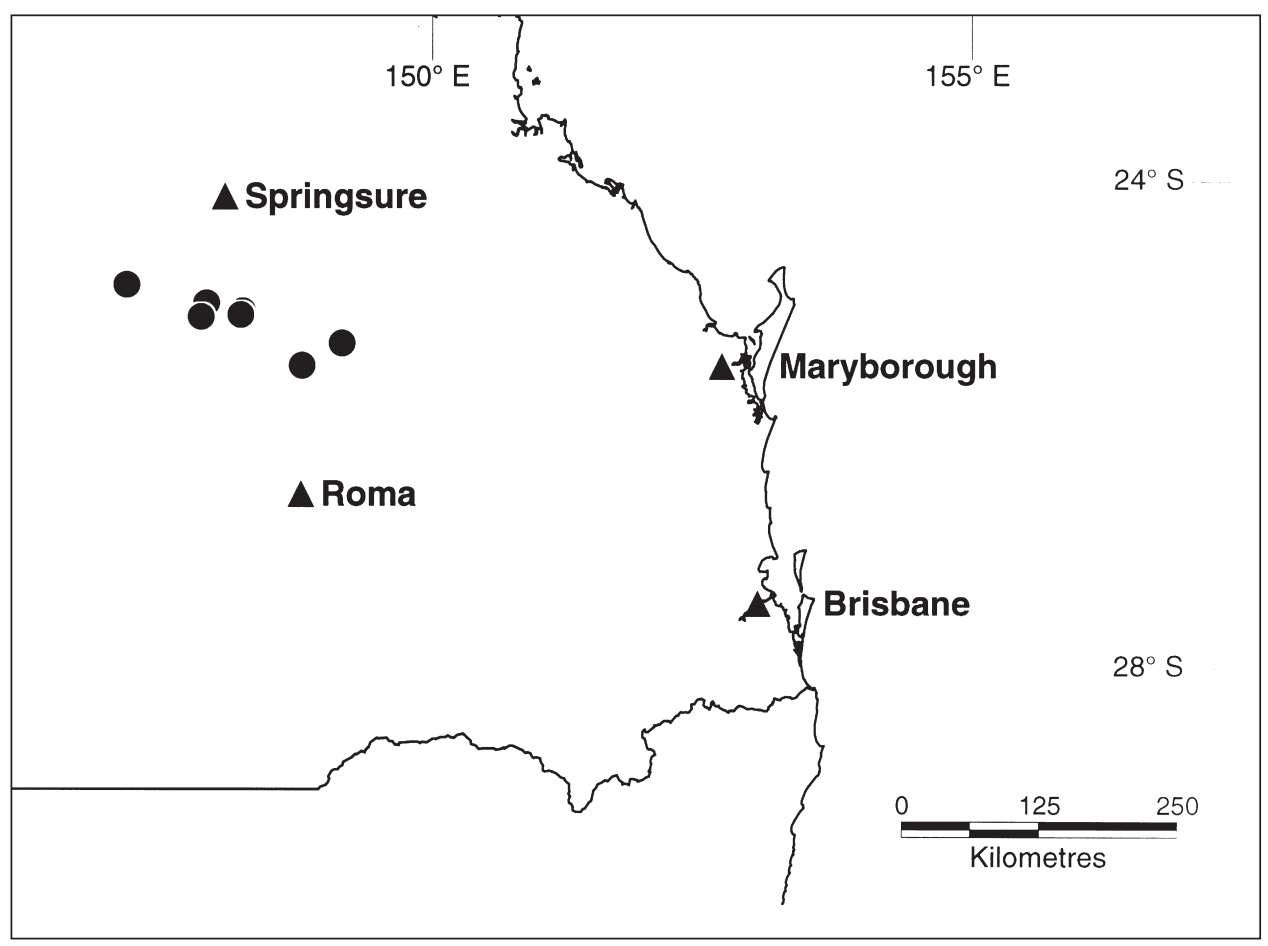

Fig. 2. Distribution map of Actinotus periculosus (•) based herbarium specimens.

\section{Acknowledgments}

The assistance of Gavin Enever and Frank Carter (Queensland National Parks and Wildlife Service), Jenny Hart and Selga Harrington (SYD), Tony Bean (BRI) and Maryann Henwood is gratefully acknowledged. Lotte von Richter generously provided unpublished data on $A$. helianthi and permitted access to plants of A. periculosus and A. helianthi cultivated at Mount Annan (Royal Botanic Gardens Sydney). This research was funded in part by the Australian Biological Resources Survey.

\section{References}

Magin, N. (1982) Blütenmorphologische untersuchungen an Actinotus Lab. (Hydrocotyloideae) unter besonderer berücksichtigung des gynoeciums. Pp.749-764 in Cauwet-Marc, A.-M. \& Carbonnier, J. (eds), Les Ombelliferes: contributions pluridisciplinaires à la systématique. [Monographs in Systematic Botany from the Missouri Botanic Garden, vol 6.] (BraunBrumfield Inc.: Ann Arbor).

Powell, J.M. (1992) Apiaceae. Pp. 87-116 in Harden, G.J. (ed.), Flora of New South Wales, vol. 3. (New South Wales University Press: Kensington). 